\title{
Effects of regular physical activity on pain, anxiety, and depression in patients with treatment-resistant arterial hypertension
}

PIOTR JAN KRUK¹, A-F, MICHAŁ NOWICKI², A, D, E, G

${ }^{1}$ Independent Public Municipal Health Centre in Rzasnia

${ }^{2}$ Department of Nephrology, Hypertension, and Kidney Transplantation, Medical University of Lodz

A - Study Design, B - Data Collection, C - Statistical Analysis, D - Data Interpretation, E - Manuscript Preparation, $\mathbf{F}$ - Literature Search, $\mathbf{G}$ - Funds Collection

Summary Background. Medical experts and professional societies commonly recommend regular physical activity to patients with arterial hypertension. However there is little evidence of the influence of physical exercise on treatment-resistant arterial hypertension.

Objectives. The aim of the study was to analyze the influence of physical activity, intensified with additional training support, and followed up with SMS reminders regarding pain, anxiety, and depression in patients with resistant hypertension.

Material and methods. The study group consisted of 53 patients, including 27 who fulfilled the criteria for resistant hypertension, and a control group of 26 patients with well-controlled blood pressure. Initially, 24-hour monitoring of blood pressure, anthropometric measurements, and measurements of body composition by means of electric bioimpedance were conducted after the third and sixth month, and a mobile activity profile was defined by means of accelerometric measurements conducted for subsequent 72 hours. The patients completed the Hospital Anxiety and Depression Scale (HADS) and the Roland and Morris Disability Questionnaire (RMDQ). The patients were advised to perform regular aerobic physical activity in accordance with the guidelines of the American Heart Association.

Results. After 6 months, the back pain score as assessed with RMDQ had reduced from $8.2 \pm 7.5$ to $6 \pm 5.9(p=0.01)$ in subjects with treatment-resistant hypertension. Similar results applied to anxiety (score $8.2 \pm 4$ vs. $9.3 \pm 4.4$ at baseline; $p=0.02$ ) and depression as measured with HADS $(5.3 \pm 3$ vs. $6.9 \pm 3.7$ at baseline; $p=0.01)$. There was a significant positive correlation between the changes in the pain score (RMDQ) and the changes in the $24 \mathrm{~h}$ and nighttime systolic blood pressure, pulse pressure, and anxiety.

Conclusions. Regular physical activity may have a beneficial effect on anxiety, depression, and pain in patients with treatmentresistant hypertension.

Key words: depression, pain, anxiety, physical activity, ambulatory blood pressure monitoring, resistant arterial hypertension.

\section{Background}

People suffering from arterial hypertension, and especially those whose hypertension cannot be effectively controlled pharmacologically - so-called treatment-resistant hypertension - are characterized by a significantly higher risk of cardiovascular incidence than are people whose blood pressure is within the norm and well-controlled [1, 2]. It is estimated that treatment-resistant hypertension occurs in $14-16 \%$ of patients treated for arterial hypertension [3].

We also discuss the correlation between the cardiovascular system and pain perception, including the participation of baroreceptor activation in arterial blood pressure regulation and the experiencing of pain [4]. Defective activity of the autonomic system with adrenergic activity dominating over the parasympathetic system is significant for chronic pain and arterial hypertension [5]. In patients with arterial hypertension, pain ailments occur very often and a connection has also been observed between them and the degree of pressure control [6]. There are reports of the positive influence of deep-brain stimulation on arterial blood pressure in people with treatment-resistant hypertension who have been treated for chronic neuropathic pain, which implies the existence of common control areas for these parameters in the central nervous system [7].

Patients treated for treatment-resistant arterial hypertension develop stronger anxiety than those whose arterial blood pressure is well-controlled [8], and the treatment of their anxiety disorders has the positive influence on hypertension treatment in this group of patients [9]. According to the Resist-Pol survey, which describes treatment-resistant hypertension patients, the incidence of depression in this group of patients amounts to about $36.8 \%$ [10].

\section{Objectives}

Systematic physical activity is commonly recommended to patients treated for arterial hypertension. The aim of the present study was to decide whether the primary health care program of intensifying physical activity supported with additional training, SMS reminders, and motivational phone calls can reduce pain, anxiety, or depression symptoms in patients being treated for treatment-resistant hypertension. 


\section{Material and methods}

Prospective and interventional research was conducted in a health care center from October 2014 to August 2015. The subjects received medical care within the primary health care system at a health center in central Poland. The research was granted permission by the bioethics commission. The patients were aged from 18-70 and their arterial hypertension was diagnosed in accordance with the 2013 guidelines of the European Arterial Hypertension and Cardiology Society [2].

The criteria for disqualification were: chronic kidney disease of degree 3 and higher (that is, with an estimated glomerular filtration rate eGFR less than $60 \mathrm{ml} / \mathrm{min}$. [11]), diagnosed mental illnesses or disorders of consciousness, considerable dysfunction of the locomotive organs or nervous system, unstable coronary disease, cerebral stroke, NYHA 2-4 phase of heart failure, respiratory diseases, heavy liver failure, and active cancerous disease.

After a review of patients' medical records at the health center, 80 patients meeting the qualification criteria were selected. Upon obtaining their written consent for participation in the research, a medical interview was conducted and the laboratory tests needed for the next stage were carried out (these included blood morphology, creatinine, glucose, alanine and asparagine transaminase, sodium and potassium concentration, as well as a general urine test). In the next stage, 53 people were selected; 26 had well-controlled arterial blood pressure (NTK) and 27 met the criteria for treatment-resistant hypertension (NTO). In the NTO, group the application of hypotension drugs from 3 different groups in therapeutic dosage together with diuretics did not result in arterial blood pressure of less than 140/90 mm Hg; Four or more other hypotension pharmaceuticals of different classes, including diuretics, were also administered [1].

The study used the following questionnaires: Hospital Anxiety and Depression Scale (HADS) $[12,13]$ and the Roland and Morris Disability Questionnaire. The latter contains 24 statements referring to activity limitations connected with backache, where each positive answer scored 1 point; thus, a score of 24 denoted maximum pain-related inefficiency $[14,15]$. The HADS scale consists of 14 questions, of which seven referred to anxiety symptoms and seven to depression symptoms. A score of 8-10 points in each category denotes the occurrence of moderate symptoms; a score of more than ten implies pathological anxiety or depression symptoms, whereas a score lower than eight denotes the norm [12]. The intensity of chronic pain ailments was estimated using a numerical scale, where 0 denotes a lack of pain and 10 denotes maximum pain $[16,17]$. Body composition measurements were carried out by means of electrical bioimpedance (using a Nutriguard-M appliance, Bianostic-AT electrodes; Data Input $\mathrm{GmbH}$, Darmstadt, Germany). An energy outlay analysis was conducted by means of a BodyMedia SenseWear armband accelerometer (BodyMedia, Inc., Pittsburgh, PA, USA) - a band worn on the subject's arm for 72 hours [18]. 24-hour arterial blood pressure was recorded by means of a Mobil-O-Graph appliance (I.E.M. GmbH, Stolberg, Germany). The interview, questionnaires, and measurements were repeated three and six months later.

Patients from both groups received guidelines on diet, healthy lifestyle, and physical activity based on The American Heart Association's Diet and Lifestyle Recommendations [19]. The guidelines were presented in writing in Polish and given orally during a ten-minute conversation. The NTO group patients additionally received written recommendations on increasing physical activity level, also based on The American Heart Association's Diet and Lifestyle Recommendations [19]. These patients attended a one-hour meeting with a physiotherapist who discussed and demonstrated stretching and strengthening exercises for some muscles. Assimilation of the information was then verified during a conversation of a few minutes. The NTO group of patients completed a self-evaluation chart. Physical activity was then modified and increased (during a short meeting) on the basis of this information. In addition, the patients were reminded three times a week, via short text message or phone call, to increase their physical activity. The content of the messages differed depending on the patient they were intended for.

The data are presented here as percentages and arithmetic means with standard deviations. The $t$-test for dependent tryouts was used for the NTO group data to compare variables with standard distribution; the Wilcoxon test was employed where the data did not meet the standard distribution condition of the Shapiro-Wilk test. The $t$-test for dependent tryouts was used for comparative description and the Mann-Whitney U-test for variables of standard distribution, whereas the Cochran $Q$-test was employed for multiply estimated dichotomous variables. Values of $p<0.05$ were taken as significant.

\section{Results}

Table 1 presents a general description of the NTO and NTK groups. The NTO group was characterized by significantly higher results in body mass, BMI, waist circumference, headaches, sleep disorders, and application of nonsteroidal pain killers.

Statistically significant differences in backaches, various pain ailments connected with everyday activity, and anxiety and depression were seen in the NTO group throughout the study. Significant differences in the scope of depression were found initially between the NTO and NTK groups (Table 2).

\begin{tabular}{|c|c|c|c|c|c|c|c|}
\hline \multirow{3}{*}{ Number of patients } & \multicolumn{3}{|c|}{ Treatment-resistant arterial hypertension } & \multicolumn{3}{|c|}{ Well-controlled arterial hypertension } & \multirow[t]{2}{*}{$p$} \\
\hline & Total & Women & Men & Total & Women & Men & \\
\hline & 27 & $16(59 \%)$ & $11(41 \%)$ & 26 & $17(65 \%)$ & $9(35 \%)$ & \\
\hline Age (years) & $55.5 \pm 9.1$ & $56.5 \pm 8.8$ & $54.2 \pm 9.9$ & $54.8 \pm 8.8$ & $55.7 \pm 8.8$ & $53.1 \pm 9.2$ & \\
\hline Body mass (kg) & $89.4 \pm 13.6$ & $85.3 \pm 14.7$ & $95.4 \pm 9.5$ & $76.3 \pm 11.6$ & $73.2 \pm 11.8$ & $82.1 \pm 9.3$ & $<0.001$ \\
\hline Height (m) & $1.66 \pm 0.1$ & $1.63 \pm 0.06$ & $1.7 \pm 0.08$ & $1.65 \pm 0.1$ & $1.6 \pm 0.05$ & $1.72 \pm 0.05$ & \\
\hline $\mathrm{BMI}\left(\mathrm{kg} / \mathrm{m}^{2}\right)$ & $32.5 \pm 5.1$ & $32.25 \pm 5.2$ & $32.9 \pm 5.3$ & $28.2 \pm 4.3$ & $28.4 \pm 4.9$ & $27.7 \pm 3.0$ & $<0.005$ \\
\hline Waist $(\mathrm{cm})$ & $109.5 \pm 12.1$ & $107.8 \pm 13$ & $111.9 \pm 10$ & $99.3 \pm 11.1$ & $98.35 \pm 12.9$ & $101 \pm 6.7$ & $<0.005$ \\
\hline $\begin{array}{l}\text { Education } \\
\text { primary } \\
\text { secondary } \\
\text { tertiary }\end{array}$ & $\begin{array}{l}15(55.5 \%) \\
9(33.3 \%) \\
3(11.1 \%)\end{array}$ & $\begin{array}{l}8(50 \%) \\
6(37.5 \%) \\
2(12.5 \%)\end{array}$ & $\begin{array}{l}7(63.6 \%) \\
3(27.3 \%) \\
1(9.1 \%)\end{array}$ & $\begin{array}{l}11(42.3 \%) \\
11(42.3 \%) \\
4(15.38 \%)\end{array}$ & $\begin{array}{l}8(47 \%) \\
5(29.4 \%) \\
4(23.53 \%)\end{array}$ & $\begin{array}{l}2(22.2 \%) \\
6(66.6 \%) \\
1(11.1 \%)\end{array}$ & \\
\hline
\end{tabular}




\begin{tabular}{|c|c|c|c|c|c|c|c|}
\hline \multirow[b]{2}{*}{$\begin{array}{l}\text { Cardiac ischemia } \\
\text { yes } \\
\text { no }\end{array}$} & \multicolumn{3}{|c|}{ Treatment-resistant arterial hypertension } & \multicolumn{3}{|c|}{ Well-controlled arterial hypertension } & \multirow[t]{2}{*}{$p$} \\
\hline & $\begin{array}{l}3(11 \%) \\
24(89 \%)\end{array}$ & $\begin{array}{l}3(19 \%) \\
13(81 \%)\end{array}$ & $\begin{array}{l}0 \\
11(100 \%)\end{array}$ & $\begin{array}{l}0 \\
26(100 \%)\end{array}$ & $\begin{array}{l}0 \\
17(100 \%)\end{array}$ & $\begin{array}{l}0 \\
9(100 \%)\end{array}$ & \\
\hline $\begin{array}{l}\text { Diabetes } \\
\text { No diabetes }\end{array}$ & $\begin{array}{l}11(41 \%) \\
16(59 \%)\end{array}$ & $\begin{array}{l}6(38 \%) \\
10(63 \%)\end{array}$ & $\begin{array}{l}5(45 \%) \\
6(55 \%)\end{array}$ & $\begin{array}{l}8(31 \%) \\
18(69 \%)\end{array}$ & $\begin{array}{l}7(41 \%) \\
10(59 \%)\end{array}$ & $\begin{array}{l}1(11 \%) \\
8(89 \%)\end{array}$ & \\
\hline $\begin{array}{l}\text { Kidney diseases } \\
\text { yes } \\
\text { no }\end{array}$ & $\begin{array}{l}5(19 \%) \\
22(81 \%)\end{array}$ & $\begin{array}{l}4(25 \%) \\
12(75 \%)\end{array}$ & $\begin{array}{l}1(9 \%) \\
10(91 \%)\end{array}$ & $\begin{array}{l}1(4 \%) \\
25(96 \%)\end{array}$ & $\begin{array}{l}1(6 \%) \\
16(94 \%)\end{array}$ & $\begin{array}{l}0 \\
9(100 \%)\end{array}$ & \\
\hline $\begin{array}{l}\text { Chronic back pain } \\
\text { yes } \\
\text { no }\end{array}$ & $\begin{array}{l}17(63 \%) \\
10(37 \%)\end{array}$ & $\begin{array}{l}11(69 \%) \\
5(31 \%)\end{array}$ & $\begin{array}{l}6(55 \%) \\
5(45 \%)\end{array}$ & $\begin{array}{l}10(38 \%) \\
16(62 \%)\end{array}$ & $\begin{array}{l}8(47 \%) \\
9(53 \%)\end{array}$ & $\begin{array}{l}2(22 \%) \\
7(78 \%)\end{array}$ & 0,08 \\
\hline $\begin{array}{l}\text { Headache } \\
\text { yes } \\
\text { no }\end{array}$ & $\begin{array}{l}15(56 \%) \\
12(44 \%)\end{array}$ & $\begin{array}{l}10(63 \%) \\
6(38 \%)\end{array}$ & $\begin{array}{l}5(45 \%) \\
6(55 \%)\end{array}$ & $\begin{array}{l}7(27 \%) \\
19(73 \%)\end{array}$ & $\begin{array}{l}6(35 \%) \\
11(65 \%)\end{array}$ & $\begin{array}{l}1(11 \%) \\
8(89 \%)\end{array}$ & $<0,05$ \\
\hline $\begin{array}{l}\text { Sleep disorders, snoring } \\
\text { yes } \\
\text { no }\end{array}$ & $\begin{array}{l}22(81 \%) \\
5(19 \%)\end{array}$ & $\begin{array}{l}14(88 \%) \\
2(12 \%)\end{array}$ & $\begin{array}{l}8(73 \%) \\
3(27 \%)\end{array}$ & $\begin{array}{l}13(50 \%) \\
13(50 \%)\end{array}$ & $\begin{array}{l}8(47 \%) \\
9(53 \%)\end{array}$ & $\begin{array}{l}5(56 \%) \\
4(44 \%)\end{array}$ & $<0,05$ \\
\hline $\begin{array}{l}\text { Smoking } \\
\text { currently smoking } \\
\text { non-smokig } \\
\text { non-smoker from < } 5 \\
\text { years ago }\end{array}$ & $\begin{array}{l}3(11 \%) \\
23(85 \%) \\
1(4 \%)\end{array}$ & $\begin{array}{l}1(6 \%) \\
14(88 \%) \\
1(6 \%)\end{array}$ & $\begin{array}{l}2(18 \%) \\
9(82 \%) \\
0\end{array}$ & $\begin{array}{l}5(19 \%) \\
18(69 \%) \\
2(12 \%)\end{array}$ & $\begin{array}{l}3(18 \%) \\
13(76 \%) \\
1(2 \%)\end{array}$ & $\begin{array}{l}2(22 \%) \\
5(56 \%) \\
2(22 \%)\end{array}$ & \\
\hline $\begin{array}{l}\text { Alcohol drinking } \\
\text { yes } \\
\text { no }\end{array}$ & $\begin{array}{l}8(30 \%) \\
19(70 \%)\end{array}$ & $\begin{array}{l}2(13 \%) \\
14(88 \%)\end{array}$ & $\begin{array}{l}6(55 \%) \\
5(45 \%)\end{array}$ & $\begin{array}{l}8(31 \%) \\
18(69 \%)\end{array}$ & $\begin{array}{l}2(12 \%) \\
15(88 \%)\end{array}$ & $\begin{array}{l}6(67 \%) \\
3(33 \%)\end{array}$ & \\
\hline $\begin{array}{l}\text { Long-term use of non- } \\
\text { steroidal anti-inflamma- } \\
\text { tory drugs } \\
\text { yes } \\
\text { no }\end{array}$ & $\begin{array}{l}8(30 \%) \\
19(70 \%)\end{array}$ & $\begin{array}{l}7(44 \%) \\
9(56 \%)\end{array}$ & $\begin{array}{l}1(9 \%) \\
10(91 \%)\end{array}$ & $\begin{array}{l}1(4 \%) \\
25(96 \%)\end{array}$ & $\begin{array}{l}0 \\
17(100 \%)\end{array}$ & $\begin{array}{l}1(11 \%) \\
8(89 \%)\end{array}$ & $<0,05$ \\
\hline $\begin{array}{l}\text { Long-term use of psy- } \\
\text { chotropic drugs } \\
\text { yes } \\
\text { no }\end{array}$ & $\begin{array}{l}7(26 \%) \\
20(74 \%)\end{array}$ & $\begin{array}{l}4(25 \%) \\
12(75 \%)\end{array}$ & $\begin{array}{l}3(27 \%) \\
8(73 \%)\end{array}$ & $\begin{array}{l}6(23 \%) \\
20(77 \%)\end{array}$ & $\begin{array}{l}5(29 \%) \\
12(71 \%)\end{array}$ & $\begin{array}{l}1(11 \%) \\
8(89 \%)\end{array}$ & \\
\hline
\end{tabular}

BMI - body mass index.

\begin{tabular}{|c|c|c|c|c|c|}
\hline & Time of test & \multicolumn{2}{|c|}{$\begin{array}{l}\text { Treatment-resistant arterial } \\
\text { hypertension } \\
p^{*} \text { value }\end{array}$} & $\begin{array}{l}\text { Well-controlled arte- } \\
\text { rial hypertension }\end{array}$ & $P$ value \\
\hline $\begin{array}{l}\text { RMDQ } \\
\text { (score) }\end{array}$ & $\begin{array}{l}\text { initially } \\
\text { 3rd month } \\
\text { 6th month }\end{array}$ & $\begin{array}{l}8.2 \pm 7.5 \\
7.2 \pm 6.7 \\
6 \pm 5.9 \\
\end{array}$ & $\begin{array}{l}0.09 \\
<0.05 \\
0.01\end{array}$ & $\begin{array}{l}4.8 \pm 5 \\
4.4 \pm 4.2 \\
5 \pm 5.3 \\
\end{array}$ & $\begin{array}{l}0.18 \\
0.21 \\
0.74\end{array}$ \\
\hline Pain vs. locomotion problems [NRS] & $\begin{array}{l}\text { initially } \\
\text { 3rd month } \\
\text { 6th month }\end{array}$ & $\begin{array}{l}3.6 \pm 3.6 \\
2.9 \pm 2.9 \\
2.4 \pm 2.5\end{array}$ & $\begin{array}{l}0.16 \\
0.09 \\
<0.01\end{array}$ & $\begin{array}{l}1.8 \pm 2.8 \\
2.3 \pm 2.7 \\
2.7 \pm 2.8\end{array}$ & $\begin{array}{l}0.08 \\
0.55 \\
0.66 \\
\end{array}$ \\
\hline Pain vs. job performance [NRS] & $\begin{array}{l}\text { initially } \\
\text { 3rd month } \\
\text { 6th month }\end{array}$ & $\begin{array}{l}4.2 \pm 3.9 \\
3.3 \pm 3.3 \\
2.2 \pm 2.4 \\
\end{array}$ & $\begin{array}{l}0.07 \\
0.02 \\
0.002 \\
\end{array}$ & $\begin{array}{l}2.3 \pm 3.1 \\
2.3 \pm 2.7 \\
2.75 \pm 2.8 \\
\end{array}$ & $\begin{array}{l}0.08 \\
0.33 \\
0.51 \\
\end{array}$ \\
\hline Pain vs. mood [NRS] & $\begin{array}{l}\text { initially } \\
\text { 3rd month } \\
\text { 6th month }\end{array}$ & $\begin{array}{l}4.5 \pm 3.9 \\
2.9 \pm 3 \\
2.55 \pm 2.8 \\
\end{array}$ & $\begin{array}{l}0.01 \\
0.81 \\
0.002 \\
\end{array}$ & $\begin{array}{l}2.8 \pm 2.7 \\
3.2 \pm 3 \\
3.3 \pm 3 \\
\end{array}$ & $\begin{array}{l}0.15 \\
0.60 \\
0.32 \\
\end{array}$ \\
\hline Pain vs. social life [NRS] & $\begin{array}{l}\text { initially } \\
\text { 3rd month } \\
\text { 6th month }\end{array}$ & $\begin{array}{l}3.3 \pm 4.2 \\
2 \pm 2.8 \\
1.7 \pm 2.7 \\
\end{array}$ & $\begin{array}{l}<0.05 \\
0.44 \\
0.02 \\
\end{array}$ & $\begin{array}{l}1.7 \pm 2.8 \\
2.5 \pm 2.8 \\
2.7 \pm 3.1 \\
\end{array}$ & $\begin{array}{l}0.15 \\
0.46 \\
0.21 \\
\end{array}$ \\
\hline Number of hours' sleep per day & $\begin{array}{l}\text { initially } \\
\text { 3rd month } \\
\text { 6th month }\end{array}$ & $\begin{array}{l}6.3 \pm 1.7 \\
6.3 \pm 1.1 \\
6.3 \pm 1\end{array}$ & $\begin{array}{l}0.86 \\
0.77 \\
0.94\end{array}$ & $\begin{array}{l}6.75 \pm 1.4 \\
6.6 \pm 1.4 \\
6.4 \pm 1.3\end{array}$ & $\begin{array}{l}0.33 \\
0.44 \\
0.47\end{array}$ \\
\hline
\end{tabular}




\begin{tabular}{|c|c|c|c|c|c|}
\hline \multirow[b]{2}{*}{$\begin{array}{l}\text { Assessment of anxiety according to } \\
\text { HADS }\end{array}$} & \multirow{2}{*}{$\begin{array}{l}\text { Time of test } \\
\text { initially } \\
\text { 3rd month } \\
\text { 6th month } \\
\end{array}$} & \multicolumn{2}{|c|}{$\begin{array}{l}\text { Treatment-resistant arterial } \\
\text { hypertension } \\
p^{*} \text { value }\end{array}$} & \multirow{2}{*}{$\begin{array}{l}\begin{array}{l}\text { Well-controlled arte- } \\
\text { rial hypertension }\end{array} \\
7.2 \pm 3 \\
7.6 \pm 3.3 \\
7.7 \pm 4 \\
\end{array}$} & \multirow{2}{*}{$\begin{array}{l}\boldsymbol{P} \text { value } \\
0.05 \\
0.84 \\
0.67 \\
\end{array}$} \\
\hline & & $\begin{array}{l}9.3 \pm 4.4 \\
7.4 \pm 3.8 \\
8.2 \pm 4 \\
\end{array}$ & $\begin{array}{l}<0.005 \\
0.19 \\
0.02 \\
\end{array}$ & & \\
\hline $\begin{array}{l}\text { Assessment of depression according } \\
\text { to HADS }\end{array}$ & $\begin{array}{l}\text { initially } \\
\text { 3rd month } \\
\text { 6th month }\end{array}$ & $\begin{array}{l}6.9 \pm 3.7 \\
5.3 \pm 3.2 \\
5.3 \pm 3\end{array}$ & $\begin{array}{l}<0.01 \\
0.79 \\
0.01\end{array}$ & $\begin{array}{l}4.65 \pm 3.2 \\
5.9 \pm 3.6 \\
5.75 \pm 4.3\end{array}$ & $\begin{array}{l}0.01 \\
0.64 \\
0.68\end{array}$ \\
\hline
\end{tabular}

HADS - Hospital Anxiety and Depression Scale; NRS - Numeric Rating Scale; $p^{*}-p$ value referring to the differences in treatment-resistant arterial hypertension group subsequently between the third month and initially, between the sixth and third month, between the sixth month and the initial measurement; RMDQ - Roland-Morris Disability Questionnaire used for assessment of spine pains.

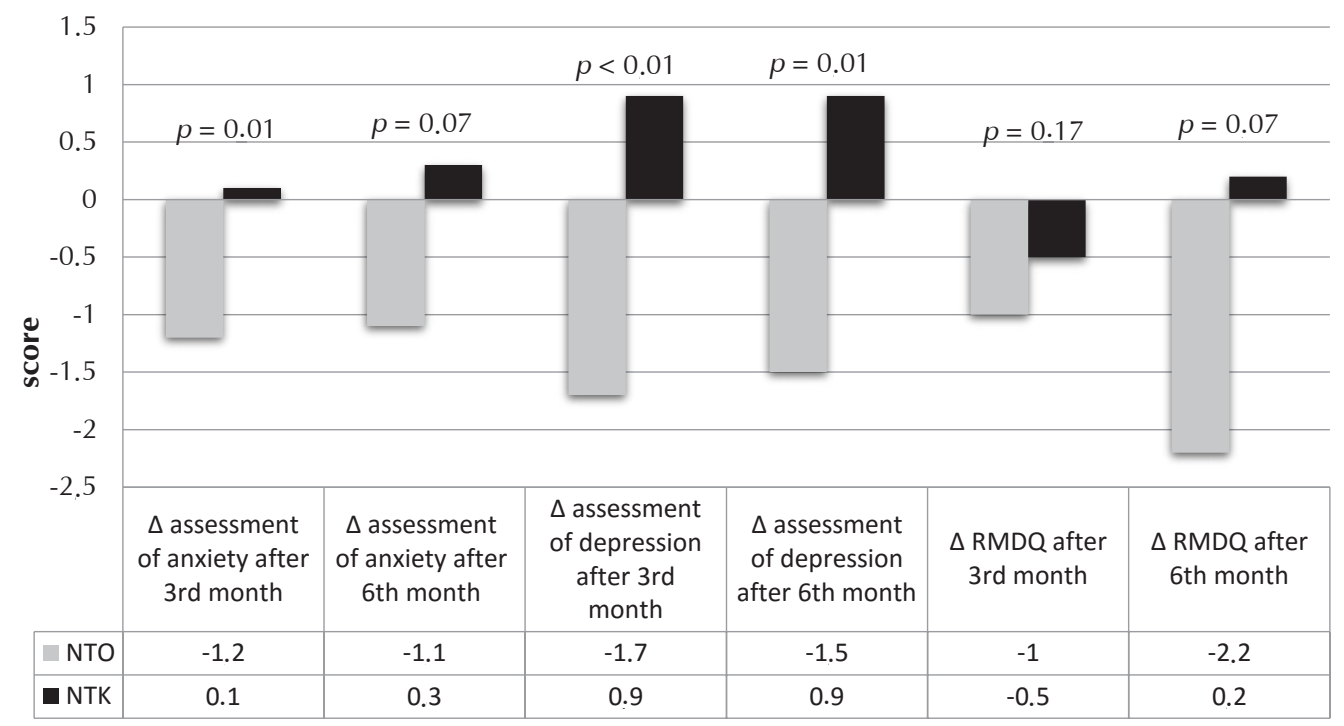

Figure 1. Changes in the scope of anxiety and depression assessed according to HADS and changes in the assessment of backaches on the basis of RDMQ questionnaire

$\Delta$ - change in the measured parameter in the specified observation time; HADS - Hospital Anxiety and Depression Scale; NTK - group of patients with well-controlled arterial blood pressure; NTO - group of patients with treatment-resistant arterial blood pressure; RMDQ - Roland-Morris Disability Questionnaire used in assessment of spinal pain.

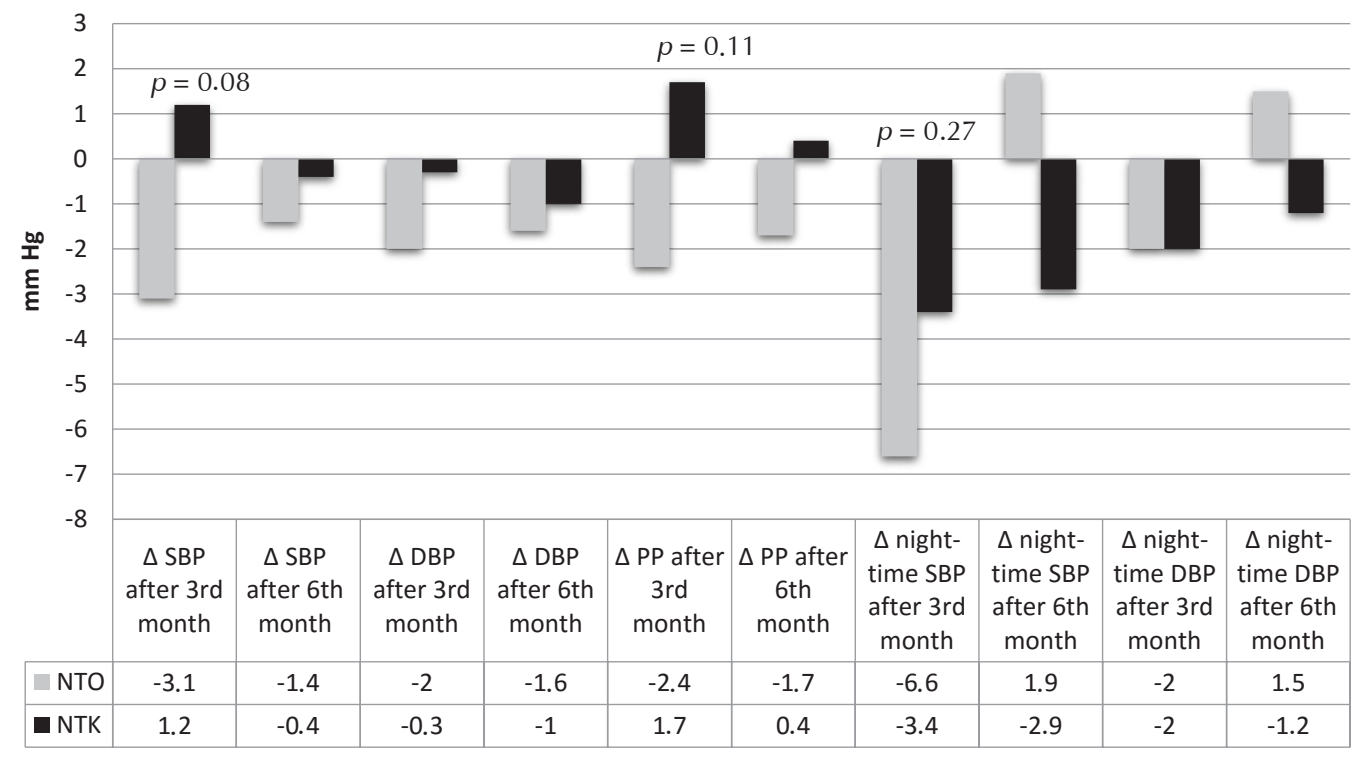

Figure 2. Changes in measurements from the 24-hour automatic recording of arterial blood pressure

$\Delta$ - change in the measured parameter during the observation time; DBP - diastolic arterial blood pressure; NTK - group of patients with well-controlled arterial blood pressure; NTO - group of patients with treatment-resistant arterial blood pressure; PP - pulse pressure; SBP - systolic arterial blood pressure. 
Figure 1 presents the changes in HADS and RMDQ scores at subsequent stages of the research. Significant differences between the groups in the assessment of depression, and differences on the edge of statistical significance in the scope of anxiety assessment and RMDQ score, were observed after the sixth month.

Figure 2 presents a comparison between NTO and NTK groups in terms of arterial blood pressure and pulse pressure changes after the third and sixth months of the study. The NTO group achieved better results after the third month than after the sixth month, but the differences between the groups were not statistically significance.

On the basis of accelerometric measurements, we noted differences on the edge of statistical significance in the number of steps performed within 3 days $(17,361 \pm 6815 \mathrm{vs}$. $20,807 \pm 8539 ; p=0.05)$ after the third month. A substantial increase in the number of steps $(17,361 \pm 6815$ vs. 23,067 $\pm 7741 ; p<0.005)$, as well as a decrease in relaxation and sedentary lifestyle time (1595 \pm 265 vs. $1458 \pm 292$ min.; $p<$ $0.05)$ were observed after the sixth month. In the NTK group, $21,374 \pm 9481$ vs. $25,779 \pm 11,201$ steps after the sixth month were recorded $(p=0.03)$ and $1520 \pm 175$ vs. $1483 \pm$ 246 min. of relaxation, after the sixth month $(p=0.15)$.

In terms of body composition, an increase in fat-free body mass $(58.8 \pm 9.8 v s .60 .1 \pm 9.9 \mathrm{~kg} ; p=0.01)$ was noted after the sixth month, and an increase in the cellular body mass close to statistical significance $(30.6 \pm 6.4$ vs. $31.7 \pm 6$ $\mathrm{kg} ; p=0.08$ ) was seen between the third and sixth month. Waist circumference decreased $(109.5 \pm 12$ vs. $108.6 \pm 12$ $\mathrm{cm} ; p=0.32)$. Body mass $(89.4 \pm 13.6$ vs. $89.5 \pm 14 \mathrm{~kg})$ and $\mathrm{BMI}\left(32.5 \pm 5.1 \mathrm{vs} .32 .6 \pm 5.3 \mathrm{~kg} / \mathrm{m}^{2}\right)$ did not change noticeably. As for the NTK group, body mass $(76.3 \pm 12 \mathrm{vs}$. $78 \pm 12 \mathrm{~kg} ; p=0.07)$, BMI $\left(28.2 \pm 4.3\right.$ vs. $28.8 \pm 4.8 \mathrm{~kg} / \mathrm{m}^{2}$; $p=0.05$ ), fat-free body mass (53.4 $\pm 9.1 \mathrm{vs} .55 .1 \pm 9.5 \mathrm{~kg}$; $p=0.001)$, and cellular body mass $(28.1 \pm 5.6$ vs. $29 \pm 5.6$ $\mathrm{kg} ; p=0.01)$ all increased, whereas the waist circumference did not change $(99.3 \pm 11$ vs. $99.4 \pm 11 \mathrm{~cm})$.

The study demonstrated a significant positive correlation between the changes in the RMDQ questionnaire and the changes in the average systolic arterial blood pressure $(r=$ $0.44 ; p=0.03)$, the average systolic arterial blood pressure at night $(r=0.42 ; p=0.04)$ and the pulse pressure $(R=0.62$; $p<0.05)$ as well as the changes in anxiety score in HADS scale $(R=0.45 ; p<0.05)$. All these imply that there exists the interrelation between the decrease in backaches and the decrease in anxiety, and lower arterial blood pressure and pulse pressure.

\section{Discussion}

The treatment-resistant arterial blood pressure patients in our study also suffered from obesity, diabetes, and kidney diseases. The patients often complained of headaches, spinal pain, snoring, and sleep disorders, and they used chronic nonsteroidal anti-inflammatory medication. Other authors have given similar descriptions of such patients and have also pointed out that elderly people and females more often suffer from treatment-resistant hypertension [1]. Sleep apnea, metabolic syndrome, depression, and primary hyperaldosteronism have been frequently in the population of Poland [10]. Our study revealed significantly higher scores for depression and anxiety (as measured by HADS) in the NTO group than in the NTK group. The study of Davies et al. does not, however, confirm these observations: in that study, patients with arterial blood pressure $\leq 160 / 90 \mathrm{~mm} \mathrm{Hg}$ were selected for the group with the well-controlled blood pressure [20]. Pain ailments often occur in patients with arterial hypertension. Krawczyk et al. stated that as many as $87 \%$ of such patients complain of various pains $(52 \%$ of headaches and $60 \%$ of pains in lower limbs); moreover, the intensity of the pain was connected with the degree of blood pressure control [6]. In our study, $56 \%$ of NTO patients complained of headaches and $63 \%$ of spine ailments. Pain ailments occurred more rarely and with lower intensity in the patients with well-controlled blood pressure.

Physical activity helps to treat depression and anxiety disorders by enhancing classical pharmacotherapy; however there are very few prospective studies discussing the issue [21]. The HADS scale proves a reliable tool to assess anxiety and depression in chronic diseases [22]. The meta-analysis of Meng et al. shows considerable reductions in HADS and RMDQ scores in patients with chronic backache who performed aerobic exercise [23]. Our study confirms a substantial decrease in HADS score for both anxiety and depression, and a positive effect was noted in the first three months when the physical activity of the patients was relatively low.

Aerobic, isometric, and resisting exercises resulted in pain alleviation in healthy adults, as well as in some people with chronic pain [24]. Physical activity may have a beneficial influence on pain alleviation by increasing the pain threshold as a result of exercise-induced hypoalgesia. The influence of the serotonin and adrenergic downward systems, as well as the effect of endogenous opioids and cannabinoids, has also been considered here [24, 25]. The type, length, and intensity of physical effort influence the nature of posteffort hypoalgesia. Works on chronic musculoskeletal pain point to the beneficial effect of physical activity and its preventative function, as well as to the improvement of the autonomic system activity [26].

Our study has a few limitations. The influence of both the placebo effect and Hawthorne's effect on the results cannot be ruled out.

Our study also has its strong points. The initiative described here is a simple, inexpensive, and accessible scheme for intensifying physical activity. It is based on an individual approach and was well-tolerated and highly valued by the patients $(85 \%$ of the patients wished to continue the exercises).

\section{Conclusion}

The systematic physical activity performed by patients with treatment-resistant arterial hypertension reduces anxiety, symptoms of depression, and pain intensity.

Source of funding: This work was funded by the Medical University of Lodz No. 503/1-151-02/503-01 grant. Conflict of interest: The authors declare no conflict of interests.

\section{References}

1. Calhoun DA, Jones D, Textor S, et al. Resistant hypertension: diagnosis, evaluation, and treatment. A scientific statement from the American Heart Association Professional Education Committee of the Council for High Blood Pressure Research. Hypertension 2008; 51(6): 1403-1419.

2. Mancia G, Fagard R, Narkiewicz K, et al. Task Force Members: 2013 ESH/ESC Guidelines for the management of arterial hypertension: the Task Force for management of arterial hypertension of the European Society of Hypertension (ESH) and of the European Society of Cardiology (ESC). J Hypertens 2013; 31(7): 1281-1357. 
3. Achelrod D, Wenzel U, Frey S. Systematic review and meta-analysis of the prevalence of resistant hypertension in treated hypertensive populations. Am J Hypertens 2015; 28(3): 355-361.

4. Koltyn KF, Umeda M. Exercise, hypoalgesia and blood pressure. Sports Med 2006; 36(3): 207-214.

5. Bruehl S, Chung OY. Interactions between the cardiovascular and pain regulatory systems: an updated review of mechanisms and possible alterations in chronic pain. Neurosci Biobehav Rev 2004; 28(4): 395-414.

6. Krawczyk JP, Adamkiewicz M, Kurnatowska I, et al. Występowanie bólu, jego charakterystyka oraz związek ze stopniem kontroli ciśnienia u osób chorujących na nadciśnienie tętnicze. Arterial Hypertens 2013; 17(3): 221-230.

7. O'Callaghan LE, McBryde FD, Burchell AE, et al. Deep brain stimulation for the treatment of resistant hypertension. Curr Hypertens Rep 2014; 16(11): 493.

8. Schmieder RE, Grassi G, Kieldsen SE. Patients with treatment-resistant hypertension report increased stress and anxiety: a worldwide study. J Hypertens 2013; 31(3): 610-615.

9. Greenage M, Kulaksizoglu B, Cilinqiroglu M, et al. The role of anxiety and emotional stress as a risk factor in treatment-resistant hypertension. Curr Atheroscler Rep 2011; 13(2): 129-131.

10. Florczak E, Prejbisz A, Szwench-Pietrasz E, et al. Clinical characteristics of patients with resistant hypertension: The RESISTPOL study. J Hum Hypertens 2013; 27(11): 678-685.

11. Levin A, Stevens P. Summary of KDIGO 2012 CKD Guideline. Behind the scenes, need for guidance, and a framework for moving forward. Kidney Int 2014; 85(1): 49-61.

12. Majkowicz M. Praktyczna ocena efektywności opieki paliatywnej - wybrane techniki badawcze. In: de Walden-Gałuszko K, Majkowicz M, eds. Ocena jakości opieki paliatywnej w teorii i w praktyce. Gdańsk: Gdański Uniwersytet Medyczny; 2000: 21-42.

13. Karakuła H, Grzywa A, Spila B, et al. Use of Hospital Anxiety and Depression Scale in psychosomatic disorders. Psychiatr Pol 1996; 7-8(30): 653-767.

14. Roland M, Morris R. A study of the natural history of back pain. Part I: development of a reliable and sensitive measure of disability in low-back pain. Spine (Phila Pa 1976) 1983; 8(2): 141-144.

15. Opara J, Szary S, Kucharz E. Polish cultural adaptation of the Roland-Morris Questionnaire for evaluation of quality of life in patients with low back pain. Spine (Phila Pa 1976) 2006; 31(23): 2744-2746.

16. Mc Quay H. Consensus on outcome measures for chronic pain trials. Pain 2005; 113(1-2): 9-19.

17. Malec-Milewska M, Zajączkowska R. Zasady stosowania opioidów w przewlekłym bólu nienowotworowym. In: MalecMilewska M, Woroń J, eds. Kompendium leczenia bólu. Warszawa: Medical Education; 2013: 67-71.

18. Trost SG, Mclver KL, Pate RR. Conducting accelerometer-based activity assessments in field-based research. Med Sci Sports Exerc 2005; 37(Suppl. 11): S531-S543.

19. The American Heart Association's Diet and Lifestyle Recommendations [cited 10.2014]. Avaible from URL: http://www.heart. org/.

20. Davies SJ, Ghahramani P, Jackson PR, et al. Panic disorder, anxiety and depression in resistant hypertension: a case-control study. J Hypertens 1997; 15(10): 1077-1082.

21. Stonerock GL, Hoffman BM, Smith PJ, et al. Exercise as a treatment for anxiety: systematic review and analysis. Ann Behav Med 2015; 49(4): 542-556.

22. Nowicka-Sauer K, Pietrzykowska M, Staśkiewicz I, et al. Lęk u pacjentów z chorobami przewlekłymi: istotny a marginalizowany problem. Fam Med Prim Care Rev 2015; 17(2): 120-123.

23. Meng XG, Yue SW. Efficacy of aerobic exercise for treatment of chronic low back pain: a meta-analysis. Am J Phys Med Rehabil 2015; 94(5): 358-365.

24. Naugle KM, Fillingim RB, Riley JL 3rd. A meta-analytic review of the hypoalgesic effect of exercise. J Pain 2012; 13(12): 1139-1150.

25. Koltyn KF, Brellenthin AG, Cook DB, et al. Mechanism of exercise-induced hypoalgesia. J Pain 2014; 15(12): 1294-1304.

26. Sabharwal L, Rasmussen N. Sluka KA, et al. Exercise prevents development of autonomic dysregulation and hyperalgesia in a mouse model of chronic muscle pain. Pain 2016; 157(2): 387-398.

Address for correspondence:

Prof. Michał Nowicki, MD, PhD

Klinika Nefrologii, Hipertensjologii i Transplantologii Nerek UM

Centrum Kliniczno-Dydaktyczne

ul. Pomorska 251

92-213 Łódź

Polska

Tel.: +48 42 201-44-00

E-mail: nefro@wp.pl

Received: 07.04.2016

Revised: 27.04.2016

Accepted: 08.05.2016 